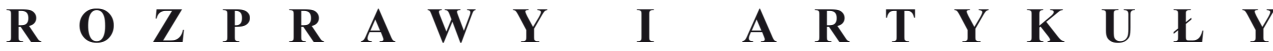 \\ Saeculum Christianum \\ t. XXII (2015), s. 5-12
}

\author{
PRZEMYSŁAW NOWOGÓRSKI \\ WNHiS UKSW, Warszawa
}

\section{EGIPSKI KONTEKST WYNALEZIENIA ALFABETU (INSKRYPCJE Z SERABIT AL-CHADIM ORAZ WADI AL-HÔL)}

\section{Wprowadzenie}

Wynalezienie pisma alfabetycznego i jego dalszy rozwój stanowią przedmiot intensywnych badań naukowych od początku dwudziestego wieku. Systematycznie przybywający, zwłaszcza dzięki pracom wykopaliskowym, materiał badawczy pozwolił na sformułowanie kilku teorii na ten temat. Wiele z nich jest dziś nieaktualnych, pozostających jedynie w sferze historii nauki ${ }^{1}$. Dość wcześnie, bo w pierwszych dwóch dekadach XX wieku, głównie na kanwie odkryć w Serabit al-Chadim (w Wadi Maghara na południu Synaju) dokonanych przez Williama Flidersa Petriego w latach 1904 - 1905, zwrócono uwagę na Egipt jako miejsce wynalezienia alfabetu ${ }^{2}$. Miało to nastąpić około połowy drugiego tysiąclecia p.n.e. Dalsze udoskonalenie alfabetu dokonało się już w Kanaanie w następnych wiekach. Niezależnie od datowania, jedno ustalenie nie uległo zmianie, a mianowicie środowisko Semitów, jako wynalazców pisma alfabetycznego. Odkrycie dwóch inskrypcji protoalfabetycznych w Wadi al-Hôl w ostatnim dziesięcioleciu dwudziestego wieku ,teorię egipską” pochodzenia alfabetu jeszcze umocniło i uczyniło ją (jak na razie) niepodważalną.

Zarówno wcześniejsze znaleziska inskrypcji protoalfabetycznych na Synaju (nazwane pismem protosynajskim), jak i te z Wadi al-Hôl datowane są na czasy Średniego Państwa $\left(2055\right.$ - 1650 p.n.e. $\left.{ }^{3}\right) \mathrm{w}$ dziejach Egiptu. Jest to okres dużego naporu plemion semickich z Kanaanu do Delty Nilu. Za czasów panowania XII dynastii podejmowane były działania w celu uszczelnienia wschodniej granicy Delty, a tym samym kontrolowania napływu do Egiptu ludów azjatyckich. Już za Amenemhata I (1976 - 1947 p.n.e. $\left.{ }^{4}\right)$ zbudowano Mur Księcia,

\footnotetext{
1 Na ten temat zob. P. Nowogórski, Kilka uwag na temat początków pisma alfabetycznego w: „Dzieje dawne i nowe. Studia. Materiały. Opinie", red D. Milewski, Warszawa 2011, s. 13-24.

2 Na temat prac wykopaliskowych ekspedycji Petriego na Synaju: W. M. Flinders Petrie, Researches in Sinai, London 1906.

3 Niektórzy badacze Okres Średniego Państwa kończą na wygaśnięciu XII dynastii i dynastię XIII włączają już do II Okresu Przejściowego - por. np. H. A. Schlögl, Starożytny Egipt. Historia i kultura od czasów najdawniejszych do Kleopatry, Warszawa 2009, s.311-312; te cezury czasowe podaję za tablicą chronologiczną w The Oxford Dictionary of Ancient Egypt, Ed. I. Shaw, Oxford 2000, s. 480; lata panowania królów egipskich tablicą chronologiczną w opracowaniu Schlögla, op. cit., s. 311-312.

4 Wszystkie daty w dalszej części tekstu (o ile nie zaznaczono inaczej) odnoszą się do czasów przed narodzeniem Chrystusa.
} 
swoistą starożytną egipską Linię Maginota, ochraniającą Deltę od strony Azji ${ }^{5}$. Tamtejsze wieże graniczne nadal umacniali i rozbudowywali następcy. Pomimo takiego zabezpieczenia napływ ludów semickich do północno - wschodniego Egiptu nie ustawał. Część z nich mogła być jeńcami wojennymi z wypraw do Kanaanu prowadzonych przez Amenemhata II (1914 1879/76) i Senusereta III (1872 - 1853/52); inni byli legalnymi przybyszami, wpuszczani pod kontrolą do Egiptu. Tych ostatnich zatrudniano przy wielkich inwestycjach państwowych (np. w oazie Fajum czy ekspedycjach górniczych na Synaju). W tekstach w tego czasu można spotkać określenie nędzni Azjaci, odnoszące się do emigrantów z Azji Przedniej, którzy stanowili jednak dość znaczną część populacji Egiptu. Znacznie słabsi od pierwszych królów XII dynastii, władcy czasów jej schyłku - Amenemhat III (1853 - 1806/05), Amenemhat IV (1806/05 - 1798/97) oraz królowa Neferusobek (1798/97 - 1794/93), nie zdołali wpłynąć na zmianę sytuacji z obecnością Semitów nad Nilem. Doszło nawet do tego, że przybysze otrzymali możliwość osiedlania się we własnym mieście. Na wschodnim brzegu peluzyjskiej odnogi Nilu Królowie z Herakleopolis (IX i X dynastia 2160 - 2020) założyli niewielką osadę Hut-Uaret (Awaris, ob. Tell al-Dabaa), rozbudowaną następnie przez Amenmhata I. To tu u schyłku panowania XII dynastii osiedlali się Kananejczycy. Wznosili domy według własnej tradycji budowlanej i prowadzili swój tryb życia. Jednak wielu z nich było już silnie zegipcjanizowanych. Warto zaznaczyć, że w Hut-Uaret mieszkali także reprezentanci innych ludów z Bliskiego Wschodu, co sprawiło, że miasto stało prawdziwym tyglem etnicznym, językowym i kulturowym.

Po XII dynastii nastąpiło panowanie o wiele słabszych władców zaliczonych przez Manethona do XIII dynastii (ok. 1793 - 1650). Wobec ogólnego kryzysu politycznego w całym Egipcie, bardzo wrażliwa granica północno - wschodnia właściwie przestała być kontrolowana, a napływ ludów semickich jeszcze się zwiększył. W efekcie doprowadziło to do stuletniej dominacji semickich Hyksosów w północnej części kraju i kolejnego rozbicia dzielnicowego Egiptu (II Okres Przejściowy).

Jednym z miejsc, w którym korzystano z pracy semickich emigrantów (ale nie byli to niewolnicy) stanowiły górnicze wyprawy na Synaj, finansowane ze skarbca państwowego.

W górach południowego Synaju eksploatowano miedź i turkusy. Przy jednej z takich kopalń (ob. Serabit al-Chadim) Senuseret I (1956 - 1911/10) wzniósł świątynię ku czci bogini Hathor - Pani Turkusów (kopalnia z przerwani była wykorzystywana aż do schyłku Nowego Państwa $)^{6}$. Jak potwierdzają znaleziska archeologiczne, turkus był bardzo cenionym materiałem jubilerskim w Egipcie. Tylko za czasów Amenemhata III zorganizowano aż 28 wypraw do kopalni w Serabit al-Chadim. Być może, że właśnie w czasie tych wypraw wynaleziony został alfabet.

\section{Pismo protosynajskie}

Dziś jest pewne, że najstarszą formą alfabetu jest pismo protosynajskie, znane z kilkudziesięciu (ponad pięćdziesiąt) inskrypcji, pochodzących głównie ze świątyni bogini Hathor w Serabit al-Chadim. Odkrycia tego dokonała brytyjska misja archeologiczna w 1905 roku (n.e.), kierowana przez Williama Flindersa Petriego. Wśród napisów wykonanych egipskim

\footnotetext{
H. Schögl, op. cit., s. 108.

6 G.D. Mumford, hasło Serabit el-Khadim w: "The Encyclopedia of Ancient History" - dostęp online od 26 IX $2012 \mathrm{r}$.
} 
pismem hieroglificznym (głównie hieratycznym), zidentyfikowane zostały także zapisane nieznanymi dotąd znakami. Petrie nie zdołał jeszcze rozszyfrować problemu, ale dziesięć lat później w 1916 roku (n.e.) inny brytyjski egiptolog, Alan Gardiner, uznał znaki te za znaki literowe, wywodzące się z egipskich hieroglifów. Wyodrębnił grupę czterech wcześniej nieznanych znaków a obecnych w inskrypcjach z Serabit. Uznał je za litery służące do zapisu wyrazów w języku kananejskiego7. Jako pierwszy wyraz odczytał Baalat - „Pani”. Gardiner uznał, że jest to semicki (kananejski) odpowiednik egipskiego imienia Hathor. Punktem wyjścia rozważań Gardinera były napisy na niewielkiej kamiennej rzeźbie sfinksa, na której wyryto napis hieroglifami egipskimi i drugi w nieznanym wcześniej systemie pisma. Inskrypcja egipska hieroglificzna nie nastręczała trudności, bo była dobrze czytelna: Umiłowana Hathor, Pani turkusów. Gardiner doszedł do wniosku, że znaki inskrypcji niehieroglificznej mają wartości literowe i zapisywały język semicki. Odczytał je w kierunku od lewa do prawa, a więc odwrotnie do powszechnego zapisu w alfabetach semickich. Taki kierunek odczytu wydawał się właściwy i umożliwił logicznie odczytać napis.

$$
\text { m-'-h-(b) } \boldsymbol{b}-\boldsymbol{-}-\mathbf{l}-[\mathbf{t}] \text { = umiłowana Baalat }
$$

$\mathrm{Na}$ ilustracji nr 1 prezentuję rysunki dwóch semickich inskrypcji z Serabit al-Chadim, które jako pierwsze poddane zostały przez Gardinera analizie badawczej. Czer-

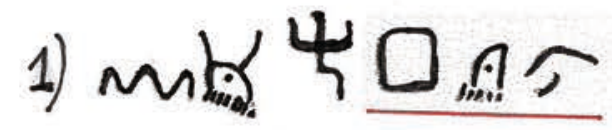
woną ramką objąłem grupę czterech znaków wskazujących na zapis alfabetyczny imienia bogini Baalat. Można je uznać za litery i nadać im wartości fonetyczne. Takie właśnie było założenie Gardinera. Znaki te przedstawiają: dom (w miarę regularny czworobok), oko, róg wołu

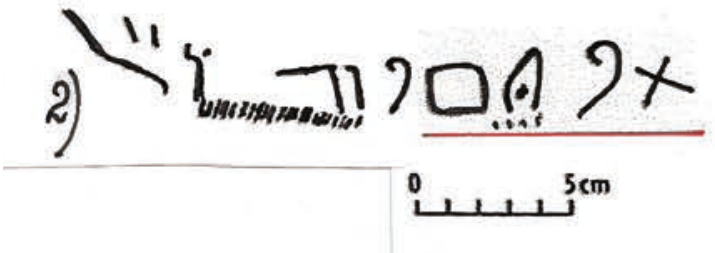

il. 1. Inskrypcja zawierająca imię Ba’alat oraz krzyż. Na inskrypcji I krzyż nie jest zbyt dobrze czytelny. Gardiner założył, że obowiązywała w tej formie zapisu zasada akrofonii, występująca w późniejszych formach alfabetów semickich (I tysiąclecie). Zasada ta polega na tym, że wartością fonetyczną danej litery jest pierwszy dźwięk jej nazwy. I tak na przykład: bêth (,dom”) to wartość fonetyczna litery $b$; 'ayin (,oko”) = dźwięk ' [hebr. ע]. Kolejna ważna obserwacja to fakt zanotowania w tych inskrypcjach tylko znaków spółgłoskowych. Innymi słowy, już u początku alfabetu semickiego wprowadzone zostały tylko litery na oznaczenie spółgłosek. Narodził się w ten sposób alfabet typu abdżad. Typ ten funkcjonował nieprzerwanie do czasu, kiedy Grecy adaptując kananejskie pismo alfabetyczne do zapisu swojego języka, wprowadzili litery odpowiadające samogłoskom. W ten sposób udoskonalili alfabet i jeszcze bardziej uprościli jego zasady ${ }^{8}$.

Na rysunku I ilustracji 1. zwraca również uwagę trzeci znak (od lewej) bardzo zbliżony swoim kształtem do egipskiego hieroglifu. (il. 2. I).

\footnotetext{
A. Gardiner, The Egyptian Origin of the Semitic Alphabet, "Journal of Egyptian Archaeology” 3; 1916, s. 1-16. 8 J. Naveh, Some Considerationson the Ostracon from Izbet Sarta, „Israel Exploration Journal “ 1978, t. 28, 1-2, s. 31-35.
} 
(a) $w q \dot{z}$

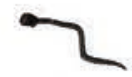

(b)

\section{żmija rogata}
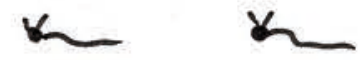

(c) hieroglif synajski

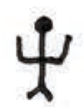

il. 2

rabit al-Chadim datowanych na czasy XII i XIII dynastii jo

Niestety, nie jest znana jego egipska wartość fonetyczna. W innych częściach Egiptu hieroglif ten nie występował, a w czasach Nowego Państwa sporadycznie używany był również na Synaju9 ${ }^{9}$ Jakie znaczenia miał w napisach semickich z Serabit? Jaką nadano mu semicką wartość fonetyczną? Mógł on stanowić graficzne odzwierciedlenie zachowania i okrzyku wydawanego przez kierownika górników w kopalniach synajskich, wyrazu notowanego jeszcze w Biblii jako „haj” (wykrzyknik: ,ach!”; ,hej!”). Tym samym, zgodnie z zasadą akrofonii, oznaczał dźwięk $h^{10}$.

Oczywistym wydaje się postawić pytanie kto i kiedy wykonał semickie inskrypcje w Serabit al-Chadim. Pytanie to obecne jest w nauce od chwili odczytania napisów przez Gardinera. W ostatnich latach ciekawą propozycję odpowiedzi na te pytania zaproponowała Orly Goldwasser, ale do tego odniosę się w dalszej części artykułu. Od czasów Gardinera niepodważalne jest stwierdzenie o Semitach z Kaananu, pracujących w synajskiej kopalni. Inskrypcje protoalfabetyczne daje się bowiem odczytać przez język tych ludów. W kolejnych latach panowało przekonanie, że wynalezienie alfabetu było efektem zetknięcia się wielu ludów i kultur w egipskim tyglu. Ale jeśli spojrzymy na sytuację robotników z egipskiej części Synaju, to raczej widzimy do pewnego stopnia ich izolację. Mamy bowiem tam do czynienia tylko z inskrypcjami egipskimi (hieroglificznymi) i protoalfabetycznymi kananejskich Semitów. Innymi słowy wydaje mi się, że było raczej odwrotnie. Najstarsza forma alfabetu narodziła się (została wynaleziona) w pewnej izolacji etnicznej i kulturowej, pod silnym wpływem pisma egipskiego. Na czym ten wpływ polegał? Czy był tylko wzorem graficznym, czy wynikał z praktyki, czyli czy wynalazca alfabetu miał umiejętność praktycznego posługiwania się pismem egipskim? I tu odpowiedzi jednoznacznej nie ma. $\mathrm{Z}$ technicznego punktu widzenia, inskrypcje protosynajskie są wykonane znacznie gorzej niż te egipskie hieroglificzne. Ma się wrażenie, że wykonały je ręce niewprawione w sztuce pisarskiej. Choć o kaligrafii w semickich napisach alfabetycznych trudno mówić również w kolejnych wiekach! Ale czy są jeszcze inne dowody mogące sugerować egipska niepiśmienność „wynalazcy” alfabetu? Na przykład inskrypcje protosynajskie nie mają jednego

\footnotetext{
$9 \quad$ Właściwie znany jest jeszcze przykład jego użycia w inskrypcji z Tell ad-Daba i kolejny z Wadi Gassus.

10 Np. hôy 'chi = ach mój bracie! (Jer 22,18); zob. także: G. J. Hamilton, The Origins of the West Semitic Alphabet in Egyptians Scripts, Washington 2006, s. 84.
} 
ustalonego kierunku pisma. Niektóre z nich zapisane są od lewej strony ku prawej, inne od prawej ku lewej, ale są również napisy z góry na dół. Taką swobodę spotkać można na innych inskrypcjach semickich, choćby z Wadi al-Hôl, które omówię poniżej. Wydaje mi się, że wynalazca alfabetu bardziej wizualnie inspirował się hieroglifami egipskimi, mniej przywiązując wagę go ich wartości fonetycznych czy znaczeniowych. Choć nie całkiem może to być dowodem na nieznajomość pisma egipskiego. Niektóre znaki egipskie mieszał, stosował zamiennie lub modyfikował. Można to zaobserwować w przypadku dwóch hieroglifów: kobry [dż] (il. 2. 2) i żmii rogatej [f] (il. 2. 3) dla zapisu dźwięku $n$ [nachaš = wą̇̇].

Nie wszystkie litery protosynajskie były inspirowane hieroglifami egipskimi. Niektóre wywodzą się niejako ze świata otaczającego ich wynalazcę. Ręka z palcami stała się wzorem dla litery $k-$ „kaf” w piśmie Kananejczyków. Dźwięk $r$ zapisano literą przedstawiającą głowę, czyli roš. Łuk kompozytowy, którego znaku brak wśród pisma egipskiego, stał się wzorem dla litery $\check{s}$ - od kananejskiej jego nazwy ša-na-nu-ma11.

W ostatnich latach krąg, z którego wywodził się wynalazca alfabetu, choć nie musiała to być jedna osoba, jest przez badaczy nieco zawężany. Ciekawą propozycję przedstawiła Orly Goldwasser ${ }^{12}$. Uważa ona, że należy proces ten powiązać z otoczeniem niejakiego Chebededa. W inskrypcjach protosynajskich jest on określany jako Brat władcy Retenu. Retenu (Reczenu) to egipska nazwa wybrzeża śródziemnomorskiego od Gazy aż po dolinę Bikaa, a nawet dalej po północną Syrię. Była dla Egiptu regionem ważnym jako bufor przed naporem ludów azjatyckich oraz ze względu na przebiegający tam szlak handlowy i komunikacyjny. Chebeded był więc Kananejczykiem, którego ojczyzna utrzymywała bliskie kontakty z Egiptem czasów Średniego Państwa. Na synajskiej steli nr 112 Chebeded przedstawiony jest jadący na ośle z towarzyszącymi mu dwoma pieszymi ${ }^{13}$. Kananjeczyk ma na głowie charakterystyczne nakrycie, przypominający kształtem kapelusz grzyba. W identycznym nakryciu głowy Chebeded występuję także na steli nr 92. Napisy na obu stelach nie wykonał wprawny w pisaniu Egipcjanin, a zapewne Kananejczyk z małymi umiejętnościami pisarskimi. Znaki nie są regularne, nierówno ułożone, niektóre wykonane zbyt blisko siebie. Z obu przedstawień wynika, że Chebeded brał udział w egipskich ekspedycjach do kopalni w Serabit al-Chadim. Skoro jego imię obecne jest w egipskich inskrypcjach hieroglificznych, musiał zajmować ważną pozycję, czyli najpewniej był szefem pracujących tam Kananejczyków. Można więc wysunąć hipotezę, że to właśnie ktoś z kręgu Chebededa był wynalazcą alfabetu. Jednak dopatrywanie się go w osobie samego Chebededa może być według mnie, zbyt naciagana hipotezą. Informacje o Chebededzie odnoszą się do synajskich ekspedycji organizowanych przez Amenemhata III (stela nr 92 datowana jest na 13. rok panowania tego króla). Również kontekst inskrypcji hieroglificznych towarzyszących protosynajskim, pozwala na datowanie początków tego pisma, a tym samym wynalezienie alfabetu na 2. połowę XIX wieku p.n.e., właśnie na czasy panowania Amenemhata III $^{14}$.

\footnotetext{
11 Hamilton, op. cit., s. 242.

12 Swój pogląd badaczka przedstawiła w obszernym i rzeczowo udokumentowanym artykule w 2012 r.: O. Goldwasser, Out of the Mists Alphabet-Redrawing the „, Brother of the Ruler of Retenu”, „Ägypten und Levante/Egypt and the Levant" 22, 2012, s. 353-374.

13 Tamże, s. 353 (fotografia i rysunek autorki); godny uwagi jest fakt, że brak na Synaju przedstawienia jakiegokolwiek Egipcjanina jadącego na osiołku.

14 Datowanie inskrypcji protosynajskich przez Gardinera i później W. F. Albrighta było nieco późniejsze - na XVIII w. p.n.e., początek Nowego Państwa (zob. A. Gardiner, The Egyptian ..., op. cit., s. 14; W. F. Albright, The
} 


\section{Inskrypcje z Wadi al-Hôl}

W roku 1993 (n.e.) John Darnell odkrył na wapiennej ścianie Wadi al-Hôl niedaleko Luksoru, przy drodze prowadzącej ze starożytnych Teb do Abydos, dwie inskrypcje, których kształt liter jest niemal identyczny z napisami protosynajskimi. Jedna z nich wykonana została w układzie horyzontalnym, drugą zaś napisano wertykalnie (il. 3. H; 3. W).

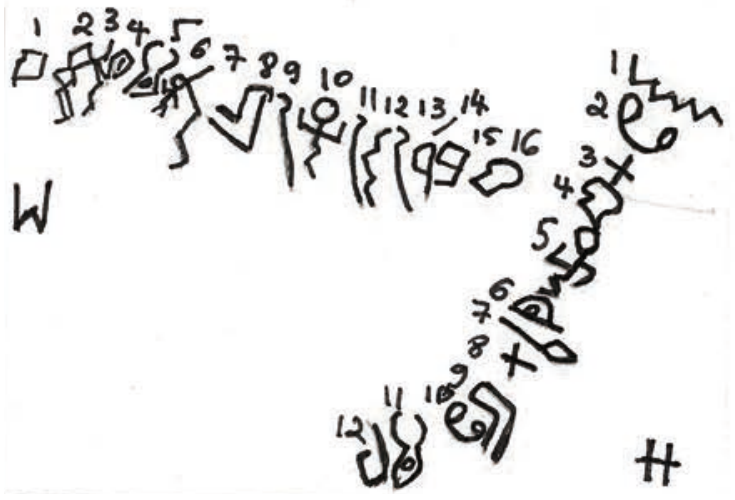

il. 3. Inskrypcje z Wadi al-Hôl

Tym samym używanie semickiego protoalfabetu potwierdzone zostało poza obszarem Synaju. Niemal natychmiast po tym odkryciu zrodziła się hipoteza o tym, że napisy te są starsze od inskrypcji z Serabit al-Chadim, a więc stanowią najstarszy przykład zastosowania protoalfabetu ${ }^{15}$. To również sugerowało, że właśnie w środkowym Egipcie nastąpiło jego wynalezienie. Hipoteza ta nie utrzymała się zbyt długo, bo nie wytrzymała krytyki naukowej. Dziś inskrypcje z Wadi al-Hôl datowanie są na schyłek Średniego Państwa - 1. połowa

XVIII wieku p.n.e. (przede wszystkim czasy XIII dynastii). Wskazują na to egipskie inskrypcje hieroglificzne, towarzyszące tym dwóm napisom semickim. Problemem okazuje się również odczytanie treść inskrypcji.

Choć na przysłowiowy pierwszy rzut oka podobieństwo napisów protosynajskich i tych z Wadi al-Hôl jest uderzające, to przy bliższej analizie pojawiają się zasadnicze różnice. $\mathrm{Z}$ technicznego punktu widzenia wydają mi się wykonane przez jeszcze mniej wprawnego w pisaniu autora niż na Synaju. Zatrzymam się tylko nad wybranymi literami, które zwróciły moją szczególną uwagę.

W inskrypcji W pierwszy znak podobny jest go egipskiego dwuzgłoskowego $m w$ i obecnej w napisach protosynajskich litery $m$. Jednak już drugi znak tej inskrypcji (oraz 11) nie ma potwierdzenia na Synaju. Jest to znak powstały z połączenia dwóch ureuszy, będący zapewne literą $\breve{s}$, od słowa šimš = słońce. Znak ten znajduje się na jednej z dwóch skalnych inskrypcji (L - lewej), odnalezionych w 2009 roku (n.e.) w Timnie w Wadi Arawah (na Negewie w Izraelu $)^{16}$. Tamte inskrypcje pochodzące również z kopalni miedzi, datowane są szeroko na okres późnego brązu i zaliczane do grupy inskrypcji protokananjeskich ${ }^{17}$.

Early Alphabetic Inscription from Sinai and their Development, "Bulletin of the American School of Oriental Research" 1948, 110, s. 6 - 22.

15 Na ten temat: J. C. Darnell et al., Two Early Alphabetic Inscriptions from the Wadi el-Hôl. New Evidence for the Origin of the Alphabet from the Western Desert of Egypt, "Annual of the American School of Oriental Research" $2005,59$.

16 Zob.: S. J. Wimmer, A Proto-Sinaitic Inscriptions Timna/Israel: New Evidence on the Emergence of the Alphabet, "Journal of Ancient Egyptian Interconnections", vol. 2, no 2, May 2010, s. 5.

17 B. E. Colles, Proto-alphabetic insriptions from the Wadi Arabah, "Antiquo Orientale: Cuadernos del Centro de Estudios de Historia del Antiquo Orientale", vol. 8, 2010, s. 78. 
Pierwsze trzy litery tworzą wyraz mšth (uczta ofiarna). Czwarta litera inskrypcji W, choć ewidentnie przypomina grzyb, jest zapisem dźwięku $r$ (przywodzi nie tylko na myśl głowę, ale również semicki kapelusz Chebededa). Dwie ostatnie litery inskrypcji W wydają się dobrze czytelne jako 'l (bóg) ${ }^{18}$. Brian Colless zaproponował odczytanie tej inskrypcji jako informacji o uczcie i ofierze (z wołu) ku czci bogini Anat ${ }^{19}$. Taka treść napisu może wynikać z treści inskrypcji egipskich, informujących o ofiarach ku czci Hathor. Imię kananejskiej bogini tworzą trzy litery inskrypcji W: 6, 7, 8 ('nth), z zastrzeżeniem, że litery 7 nie odczyta się jako w. Istnieje bowiem taka możliwość.

Inskrypcja H nastręcza więcej trudności. Odczytując ją od strony prawej (zgodnie z zapisem semickim) pierwsza litera to $r$, druga zaś to $b$, o kształcie znanym i rozpowszechnionym w inskrypcjach protokananejskich i późniejszych (fenickich i starohebrajskich). Oczywiście takie zestawienie liter przywodzi skojarzenie z wyrazem $r b$ w znaczeniu kierownik, przywódca). W inskrypcji tej uwagę zwraca dwukrotne występowanie litery $h$, wzorowanej na Hieroglifie synajskim $(7,11)$. Powstaje pytanie czy należy odczytywać je jako dźwięk $h$, czy pełnią one w tym przypadku inną rolę? Nie ma na to pytanie jednoznacznej odpowiedzi. Możliwe jest potraktowanie ich jako determinatywów wskazujących, że kolejny wyraz odnosi się do szeroko pojętej kategorii człowiek. Ponieważ zabieg taki znany jest z zapisów hieroglificznych na Synaju, mógł być zastosowany i w omawianym przypadku. Tym samym inskrypcje z Wadi al-Hôl byłyby silniej poddane wpływowi egipskiemu niż napisy protosynajskie, ale jednocześnie nie są w pełni zapisem alfabetycznym.

\section{Podsumowanie}

Z powyższych rozważań nasuwa się kilka wniosków. Jeden jest zasadniczy co do miejsca i czasu wynalezienia alfabetu. Nadal pierwszeństwo to przysługuje inskrypcjom protosynajskim i Serabit al-Chadim jako miejscu tego wynalazku. Nie zmieniły tego stanu rzeczy ani okrycia w Wadi al-Hôl ani w Wadi Arawah. Mimo stu lat badań nad inskrypcjami protosynajskimi (w przyszłym roku będzie stulecie pierwszych ustaleń Alana Gardinera) dają one coraz to nowe możliwości interpretacyjne, które jeszcze bardziej rozwiązują powiązane z nimi problemy. Można już niejako spersonalizować krąg, z którego pochodził wynalazca lub wynalazcy alfabetu, uściślić czas jego wynalezienia (panowanie, choć długie, Amenmhata III). Możliwa jest również teza o wynalezieniu alfabetu w izolacji etnicznej i kulturowej. To zagadnienie będzie jeszcze długo dyskutowane w nauce. Znaleziska w Wadi al-Hôl pokazały, że semicki alfabet nie tylko przeniesiony został do Kanaanu i tam się dalej rozwijał, ale był używany także w innych częściach Egiptu. Jak widać na przykładzie tych dwóch inskrypcji, był on silnie poddany tu wpływom egipskim. O dalszym kananejskim rozwoju pisma alfabetycznego świadczą odkrycia sprzed kilku lat w południowym Izraelu, które zasilają niezbyt liczną grupę inskrypcji protokananejskich. Najwięcej bowiem znalezisk epigraficznych dotyczy rozwiniętego już alfabetu kananejskiego - fenickiego i starohebrajskiego.

Można jedynie żywić nadzieję, że kolejne lata przyniosą kolejne odkrycia, które potwierdzą lub zmodyfikują dzisiejsze poglądy.

18 W inskrypcjach protosynajskich wyraz El występuje trzykrotnie (nr nr 363, 377, 378).

19 B. E. Colles, op. cit., s. 91. 


\section{Egyptian Context of the Beginnings of the Alphabet Summary}

The article presents the beginnings of alphabetic writing in Sinai (Serabit al-Chadim) in the context of the Egyptian hieroglyphic writing and the subsequent early alphabetic inscriptions from Wadi al-Hôl (Egypt) and Wadi Arava (Israel). In the light of the present state of research it can be concluded that the oldest alphabet (type: abgad) was established Semites working in the copper mines in Sinai under the rule of Egypt, probably in the nineteenth century BC. Direct effects on Semitic alphabetic writing had Egyptian hieroglyphs. Discovered in recent years alphabetic inscriptions in the Wadi al-Hôl and Wadi Arava turned out to be younger than the Sinaic inscriptions and are another element in the early development of alphabetic writing.

Keywords: archaeology, hieroglyphs, alphabet, Egypt, Sinai Peninsula

Nota o Autorze: dr Przemysław Nowogórski - archeolog i historyk, specjalizujący się w archeologii i historii starożytnego Izraela (zwłaszcza okres rzymski) oraz początkach i rozwoju pisma alfabetycznego. 